\title{
Articulo Original / Original Article Ethno-epidemiological study of medicinal products and medicinal plants use among pregnant women
}

[Estudio etnoepidemiológico de medicamentos y uso de plantas medicinales en mujeres embarazadas]

\section{Rosana da Matta ${ }^{1}$, Jesse Lahos Borges ${ }^{2}$, Ulisses Nilo Landi ${ }^{2}$, Lidiane Nunes Barbosa ${ }^{2}$, Amandha Lara ${ }^{1}$, Luciana Kazue Otutumi ${ }^{2}$, Antônio Sergio Ferraudo ${ }^{3} \&$ Daniela Dib Gonçalves $^{1}$}

\footnotetext{
${ }^{1}$ Programa de Pós-Graduação em Plantas Medicinais e Fitoterápicos na Atenção Básica de Saúde, Universidade Paranaense, Umuarama, Paraná, Brazil

${ }^{2}$ Programa de Pós-Graduação em Ciência Animal com Ênfase em Produtos Bioativos, Universidade Paranaense, Umuarama, Paraná, Brazil

${ }^{3}$ Faculdade de Ciências Agrárias e Veterinárias, Universidade Estadual Paulista. Jaboticabal, São Paulo, Brazil
}

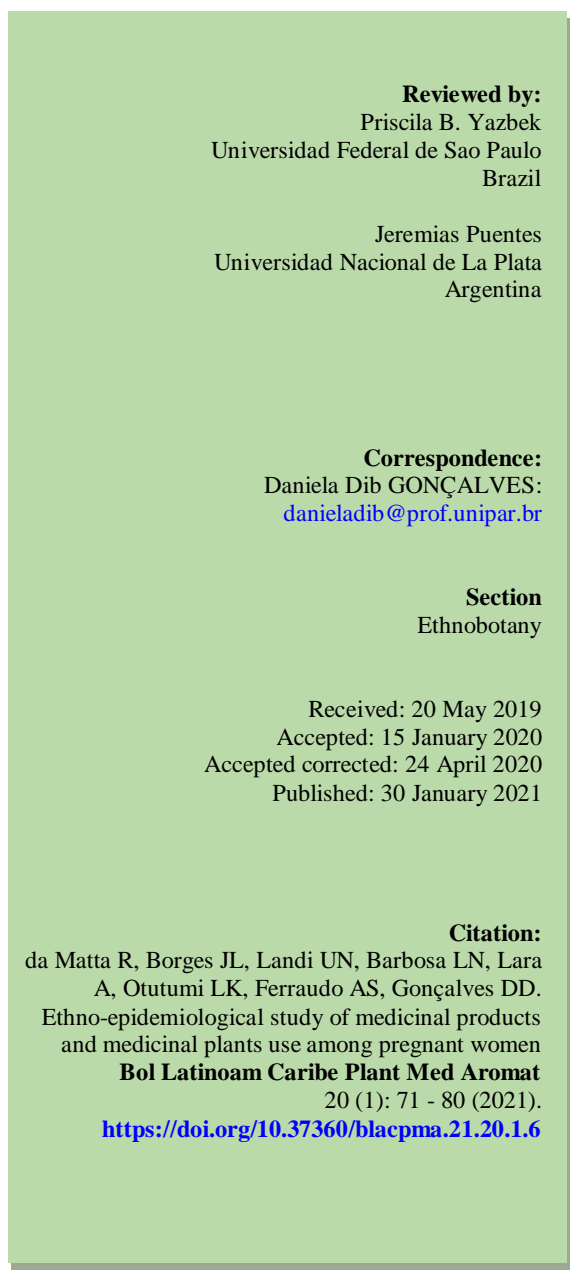

Abstract: The objective of this study was to examine the profile of pregnant women who visited the Unified Health System of the municipality of Umuarama/PR and to analyze their use of drugs categorized as D and X according to the United States Food and Drug Administration FDA and contraindicated medicinal plants for evaluating the potential gestational risks. A cross-sectional ethnoepidemiological study using a questionnaire was conducted among 500 pregnant women from January to May 2017. According to the pregnant women, during the prenatal period, $67.8 \%$ did not receive information on the use of medicinal plants and $26.6 \%$ used contraindicated plants. Among the drugs used, $12.2 \%$ belonged to category "D" (anticonvulsants), and 2.4\% belonged to category " $\mathrm{X}$ " (hormonal contraceptives). This work highlights the need to expand health promotion activities to the basic units and implement protocols and technical guidance tools as well as training of pharmaceutical professionals to educate the population on the risk of these drugs during pregnancy.

Keywords: Phytotherapy; Maternal Health; Integral assistance to health; Pharmaceutical care; Infant mortality; Patients'safety.

Resumen: El objetivo de este estudio fue examinar el perfil de las mujeres embarazadas que visitaron el Sistema Único de Salud del municipio de Umuarama/PR y analizar el uso de medicamentos clasificados como D y X según la Administración de Alimentos y Medicamentos de los Estados Unidos (FDA) y plantas medicinales contraindicadas por posibles riesgos gestacionales. Se realizó un estudio etnoepidemiológico transversal a través de un cuestionario realizado entre 500 mujeres embarazadas en el período enero a mayo de 2017. Según las mujeres embarazadas, durante el período prenatal, el $67.8 \%$ no recibió información sobre el uso de plantas medicinales y el $26,6 \%$ respecto de plantas contraindicadas. Entre los medicamentos utilizados, el $12,2 \%$ pertenecía a la categoría "D" (anticonvulsivos), y el 2,4\% pertenecía a la categoría "X" (anticonceptivos hormonales). Este trabajo destaca la necesidad de ampliar las actividades de promoción de la salud a las unidades básicas e implementar protocolos y herramientas de orientación técnica, así como la capacitación de profesionales farmacéuticos para educar a la población sobre el riesgo de estos medicamentos durante el embarazo.

Palabras clave: Fitoterapia; Salud maternal; Asistencia integral a la salud; Cuidado farmacéutico; Mortalidad infantil; Seguridad de los pacientes. 


\section{INTRODUCTION}

Infant mortality rate is an important indicator of the health of a country as it reflects the quality and access to health services, the socio-economic conditions of public health practices, as well as women's health status (Rocha et al., 2013). According to the Paranaense Institute of Economic and Social Development - IPARDES (2017), the infant mortality rate of Umuarama/PR is 13.60 per 1,000 live births. The prevention of obstetric complications and education of women in the pregnancy-puerperal cycle are essential (Silva et al., 2015). As no medicine is free of toxicity to the mother or fetus, and there may beteratogenic risk including abortion, death or congenital malformations, the irrational use of medications during pregnancy should be considered a public health problem (Rocha et al., 2013).

In Brazil, the potential fetal risks associated with different medications have been categorized as per the Food and Drug Administration (FDA) groupings as A, B, C, D, and X. According to Lacy et al. (2009), medications labeled by the FDA as "A" have the possibility of fetal harm appears remote; those labelled as "B" have no controlled studies in humans, but in animals showed no risks and for those labelled as "C" the risk/benefit ratio should be assessed since there is potential for adverse effect on the fetus after its use. The FDA category " $D$ " includes drugs for which there is positive evidence of fetal risk, but the benefits can be acceptable despite the risks; the category " $\mathrm{X}$ " drugs are considered contraindicated for use in pregnancy due to evidence of fetal risk from animal or human studies, or on the basis of human experience (Zomerdijk et al., 2015). According to RDC no. 60, from Dezember $17^{\text {th }} 2010$ (ANVISA, 2010), categories A, B, C, D, and X medications include folic acid (vitamin supplement), paracetamol (analgesic), omeprazole (anti-ulcer), valproic acid (anticonvulsant), and ethinyl estradiol (hormonal contraceptive), respectively.

In most countries, herbal medicines are available without a prescription. Given this ease of access, the majority of women report that they make decisions regarding use of herbal medicines on their own or based on the recommendation of family and/or friends (Kennedy et al., 2016). Medicinal plants play a significant role on the treatments associated with the women's health such as venereal disease, gynecological inflammation, promove fertility or avoid pregnancy; and according to Yasbek et al. (2016), the data of ethnopharmacology on medicinal plants used in women's health can contribute to reduce the mortality rate, either through pharmacological studies to prove their efficacy or toxicological studies to assess their safety.

Regarding the use of herbal medicines, there are regional differences in the traditions (Kennedy et al., 2016), and this is reflected in the differences across studies. Moreover, as pointed out by Smeriglio et al. (2014), the evidence from safety studies are often not conclusive. However, understanding the use of herbal medicines is important for both pregnant women and health professionals. Moreover, the Resolution 1,757, 18 February 2002, (Diario Oficial, 2012), reiterates the need to adopt strategies to improve the health of pregnant women.

Epidemiological studies are important for understating disease and behavior patterns as well as assisting public health professionals in the implementation of specific policies and programs to address population health challenges. According to Monteiro \& Brandelli (2017), ethnobotanics studies demonstrate the relationship between plants and people, and enable the collection of relevant information about the use of medicinal plants. The objective of this work was to assess the profile of pregnant women seen by the Unified Health System (SUS) of Umuarama/PR including theiras socioeconomic status, gestational health, use of drugs during and after pregnancy, as well as examine the potential risks of pregnancy from the use of medications classified as " $D$ " and " $X$ " and medicinal plants contraindicated during pregnancy.

\section{MATERIAL AND METHODS Place of study and Sampling}

A cross-sectional, ethno-epidemiological study was carried out among pregnant women of SUSbetween January and May 2017 at 24 points of care in the municipality of Umuarama/PR. To determine the sample size, Epi Info ${ }^{\mathrm{TM}}$ system was used, considering the estimated population of the municipality in 2017. According to the Brazilian Institute of Geography and Statistics (IBGE, 2020), there were 109,955 inhabitants and 2,000 pregnant women registered with the SIS-PRENATAL.

The sample consisted of 500 pregnant women, with a confidence interval of $95 \%$ for the purpose of standardization. It was determined that the number of samples per Unit of Health would be the total number of pregnant women enrolled in the establishment and we adopted a minimum target of $70 \%$ participation rate. The population of Umuarama/PR attend 24 health units (US) for prenatal care, and obstetric specialist care is delivered at 
the medical support of the Maternal-infant Reference Center and Maternity Hall - Norospar.

The interviews were conducted at the US and the pregnant women who agreed to participate in the study signed the informed consent form. The USsarehealth care facilities that provide basic support and is the closest point of contact to most people's homes.Based on the risk stratification performed by the doctor and local nurse, the pregnant woman can be referred to the Maternal-infant Reference Center and Maternity Hall - Norosparto see an obstetriciansfor specialized services.

In the basic health support of the US, the professionals prioritized by local management are doctors, nurses, dentists and community health agents. However, some units also have pharmacists for providing pharmaceutical care.

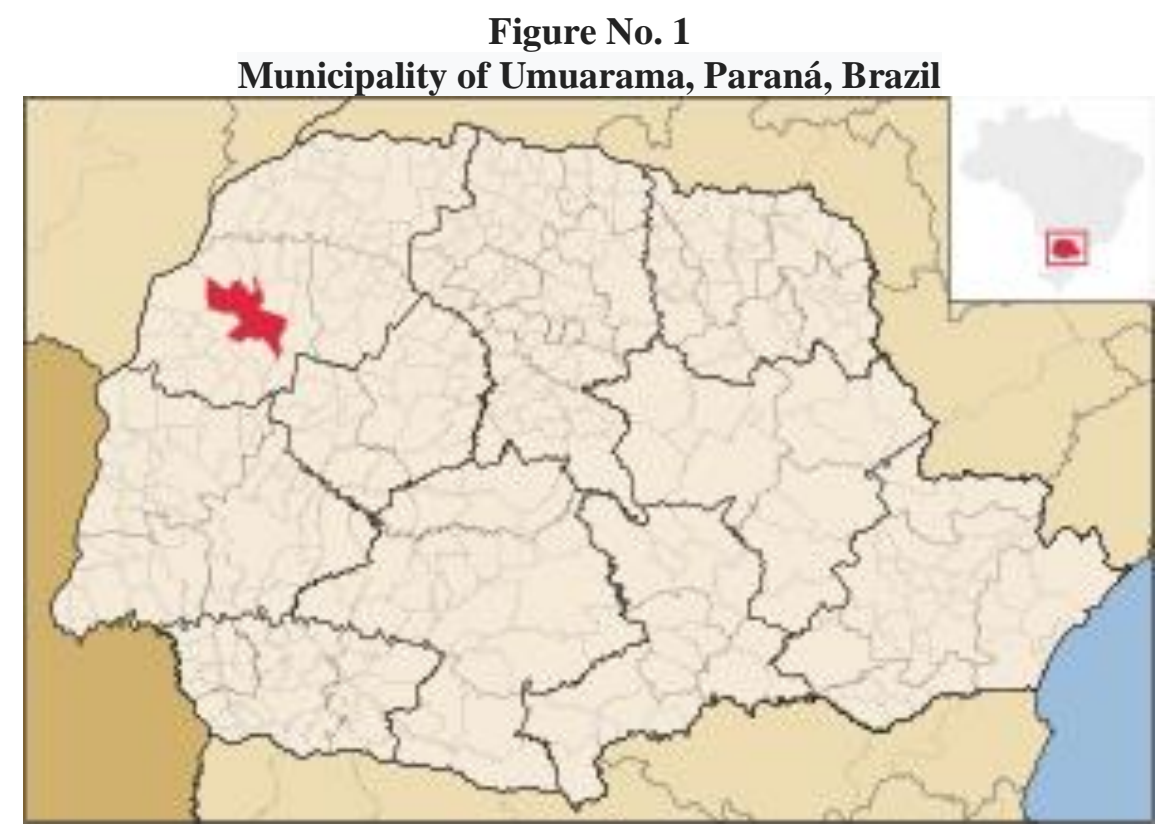

Ç

Source: Wikipedia (2019)

\section{Research instrument}

The data collection instrument was a questionnaire that collected socio-demographic data and information about general obstetric health. The questionnaire includedquestions regarding age, schooling, marital status, gestational week, risk rating, number of consultations, history of live births, miscarriages and/or stillbirths, as well as questions related tothe use of medicinal products and medicinal plants.For the medicinal products and medicinal plants, participants reported their level of consumption, prior knowledge about contraindications, and preference for using medicinal plants and their derivatives over conventional therapy.

\section{Statistical Analysis}

The prevalence of use of medicinal products and medicinal plantswas analyzed according to socio- demographic characteristics and obstetric health status. The drugs were categorized according to the List II of Annex I of RDC No. 60 of December 17, 2010, and for medicinal plants, Resolution 1,757, 18 February 2002, Rio de Janeiro State was used as the reference.

The results obtained from the use of drugs and medicinal plants contraindicated in pregnancy were compared using Chi-squared test $\left(\mathrm{x}^{2}\right)$ with Yates correction or Fisher's test and, when applicable, the Odds Ratio was calculated alongside $95 \%$ confidence interval using the IBM SPSS v 21.0 statistical software. In addition, in order to examine the association between categories, Multiple Correspondence Analysis (MCA) was performed using the Burt table, in which variables related to the number of pregnancies, abortion history, stillbirths and live births, gestational risk, use of medicines and medicinal plants, preference to use medicinal plants, 
self-assessment of use, presence of contraindicated medicinal plants in pregnancy and use of FDA category " $\mathrm{D}$ " and " $\mathrm{X}$ " drugs were examined. The results were categorized into those with intense correlation (greater than 1.96 for $\alpha=5 \%$ ) or less intense correlation (greater than 1.60 for $\alpha=10 \%$ ).

\section{Ethical Aspects}

This project was approved by the Platform Brazil Committee on Ethics in Research Involving Humans under protocol CAAE no: 61132316.0.0000.0109 and also by the Department of Health of the municipality of Umuarama/PR.

\section{RESULTS}

In this study, 500 women aged 18-45 years were interviewed. The mean age was $26.84 \pm 5.85$ years. With the exception of units of New Jerusalem and Vila Nova Uniao, which did not have pregnant women enrolled in this period, the interviews were carried out in the other 22 US.The US district of Vitória Régia had the highest number of pregnant women interviewed with 87 women being interviewed, while the US district of Roberto Silveira had the lowest number of interviews, with only one pregnant woman being enrolled.

The sample consisted predominantly of pregnant women with family incomes of up to two times the minimum wage $(66.2 \%)$. Moreover, most had complete or incomplete secondary education $(63.4 \%)$, were in a stable union $(47.8 \%)$ or officially notarized (44.6\%), interviewed in the 3rd quarter of pregnancy $(46.2 \%)$, classified as being of normal gestational risk (46.6\%), had held up to four pre-natal consultations $(49.8 \%)$, had up to two pregnancies (71\%), experienced live births in previous pregnancies (46\%), 13.8 and 1.4 had abortions and stillbirths, respectively (Table No. 1).

Table No. 1

Characteristics of pregnant women interviewed in the municipality of Umuarama, Paraná, Brazil from January to May 2017

\begin{tabular}{lll}
\hline VARIABLES & $\mathbf{N}$ & \% \\
\hline Income & 331 & 66.2 \\
Up to 2 minimum wages & 152 & 30.4 \\
Up to 4 minimum wages & 17 & 3.4 \\
More than 4 minimum wages & & \\
Educational Level & 92 & 18.4 \\
Elementary school & 317 & 63.4 \\
High School & 91 & 18.2 \\
Higher Education & & \\
Marital Status & 27 & 5.4 \\
Single & 239 & 47.8 \\
Common law marriage & 223 & 44.6 \\
Marriage & 10 & 2 \\
Divorced/separated & 1 & 0.2 \\
Widow & & \\
Gestational age & 76 & 15.2 \\
1-12th week & 193 & 38.6 \\
13- 24th week & 231 & 46.2 \\
25- 40th week & & \\
Number of Consultations Pre-Natal & 249 & 49.8 \\
Up to 4 & 138 & 27.6 \\
5 to 7 & 113 & 22.6 \\
More than 8 consultations & & \\
Risk classification & 34 & 6.8 \\
Unknown & 233 & 46.6 \\
Usual & 90.6 \\
Intermediate & 143 & 18. \\
High & 355 & 28.6 \\
Number of pregnancies & & 71 \\
Up to 2 & & \\
\hline
\end{tabular}




\begin{tabular}{lll}
\hline From $\mathbf{3}$ to $\mathbf{4}$ & 127 & 25.4 \\
More than $\mathbf{5}$ & 18 & 3.6 \\
$\begin{array}{l}\text { Presence of live births } \\
\text { None }\end{array}$ & 219 & 43.8 \\
$\begin{array}{l}\text { All of them } \\
\text { Partial }\end{array}$ & 230 & 46 \\
Presence of stillbirths & 51 & 10.2 \\
None & & \\
All of them & 493 & 98.6 \\
Partial & 2 & 0.4 \\
Presence of Abortions & 5 & 1.0 \\
None & & \\
All of them & 431 & 86.2 \\
Partial & 22 & 4.4 \\
\hline TOTAL & 47 & 9.4 \\
\hline
\end{tabular}

Source: Elaborated by the author

With respect to the use of medicinal products and medicinal plants in pregnancy, the majority (78.4\%) used only medication during pregnancy, and there was a single case of a pregnant woman who only used medicinal plants but was marked as an exception and excluded from the multivariate analysis. Moreover, $67.8 \%$ of pregnant women replied that they had not informed and/or have not been questioned by health professionals during the pre-natal period with respect to the use of medicinal plants, although, the use of medicinal plants contraindicated in pregnancy was observed in $26.6 \%$ of the sample, and $26.2 \%$ were unaware that they were using drugs and medicinal plants contraindicated during the gestational period. In a selfassessment, $66.6 \%$ of pregnant women said they do not use medicinal plants and $68.8 \%$ had no preference to use phytotherapy over traditional medicines (Table No. 2).

Table No. 2

Characterization of pregnant women interviewed in health units of the municipality of Umuarama, Paraná, Brazil from January to May, 2017

\begin{tabular}{lll}
\hline VARIABLES & $\mathbf{n}$ & $\%$ \\
\hline Use of products during pregnancy & & \\
$\begin{array}{l}\text { Yes, medications and medicinal plants } \\
\text { Yes, only medications }\end{array}$ & 63 & 12.6 \\
$\begin{array}{l}\text { Yes, only medicinal plants } \\
\text { No, none of them. }\end{array}$ & 1 & 78.4 \\
$\begin{array}{l}\text { Information and/or questioning of the health care } \\
\text { professional regarding the use of the products }\end{array}$ & 44 & 0.2 \\
$\begin{array}{l}\text { No, none of them. } \\
\text { Yes, medications and medicinal plants }\end{array}$ & 59 & \\
$\begin{array}{l}\text { Yes, only medications } \\
\text { Presence of use of drugs of FDA Category "D" during } \\
\text { pregnancy }\end{array}$ & 102 & 11.8 \\
$\begin{array}{l}\text { Yes } \\
\text { No }\end{array}$ & 339 & 20.4 \\
$\begin{array}{l}\text { Presence of use of drugs of FDA Category "X" during } \\
\text { pregnancy }\end{array}$ & 61 & 67.8 \\
Yes & 439 & \\
No & & 87.8 \\
$\begin{array}{l}\text { Presence of the use of medicinal plants contraindicated in } \\
\text { pregnancy }\end{array}$ & 12 & \\
\hline
\end{tabular}




\begin{tabular}{lll}
\hline Yes & 133 & 26.6 \\
No & 367 & 73.4 \\
$\begin{array}{l}\text { Presence of knowledge about the contra-indication of } \\
\text { medicinal plants and medicines in pregnancy }\end{array}$ & \\
Yes & 369 & 73.8 \\
No & 131 & 26.2 \\
$\begin{array}{l}\text { Preference to use medicinal plants and derived rather than } \\
\text { the traditional medicines }\end{array}$ & \\
Yes & 156 & 31.2 \\
No & 344 & 68.8 \\
Self-evaluation of the use of medicinal plants & & \\
Do not use & 333 & 66.6 \\
Rarely & 49 & 9.8 \\
Hardly ever & 82 & 16.4 \\
Regular & 36 & 7.2 \\
Reference in case of doubts of medicinal plants and & & \\
medicines & & \\
Family members and friends & 104 & 20.8 \\
Health Professionals & 138 & 27.6 \\
Health Institutes & 142 & 28.4 \\
Internet and others & 116 & 23.2 \\
\hline TOTAL & 500 & 100 \\
\hline
\end{tabular}

Source: Elaborated by the author

Table No. 3

Analysis of the association between the use of contraindicated medicinal plants in pregnancy and previous knowledge of contraindications of pregnant women interviewed in the Health Units of the municipality of Umuarama, Paraná during the period from January to May, 2017

\begin{tabular}{|c|c|c|c|c|c|c|}
\hline \multirow{2}{*}{\multicolumn{2}{|c|}{ Value }} & \multirow{2}{*}{\multicolumn{2}{|c|}{$\begin{array}{l}\text { Prior knowledge } \\
\text { of contra- } \\
\text { indications }\end{array}$}} & \multirow[t]{2}{*}{ Odds ratio } & \multirow{2}{*}{\multicolumn{2}{|c|}{$95 \%$ confidence interval }} \\
\hline & & & & & & \\
\hline \multirow{2}{*}{$\begin{array}{l}\text { Presence of } \\
\text { medicinal plants } \\
\text { contraindicated }\end{array}$} & No & 111 & 256 & \multirow{2}{*}{2,450} & \multirow{2}{*}{1,449} & \multirow{2}{*}{4,142} \\
\hline & Yes & 20 & 113 & & & \\
\hline
\end{tabular}

\section{Source: Elaborated by the author}

The use of FDA category "D" and "X" drugs was observed in $12.2 \%$ and $2.4 \%$ of pregnant women, respectively, with a slight preference for seeking drug information from some type of health establishments $(28,4 \%)$, followed by directly seeking information from health professionals $(27,6 \%)$. Among the women interviewed, the average number of medications used during pregnancy was 4.1 and the average number of medicinal plants used was 0.5 .

From the analysis, women without prior knowledge of contraindicated medicinal and herbal products in pregnancy had twice higher odds of using these products compared to those with prior knowledge, as shown (Table No. 3).
The MCA demonstrated an intense correlation between pregnant women of intermediate and high risk in relation to a history of the presence of abortions and/or partial births, the preference of alternative medicine to conventional medicine among those who regularly use medicinal plants and the use of "D" and "X" drugs with the use of medicinal plants contraindicated in pregnancy. Moreover, there was a less intense but present correlation among pregnant women with regular self-evaluation of medical plants with high risk classification, as well as high risk classification among those who were using medicinal plants and medications at the time of the interview. 
Table No 4

Report of use of medicinal plants contraindicated use in pregnancy by pregnant women in Umuarama during the gestational period for the period January to May, 2017

\begin{tabular}{lll}
\hline Popular name & Scientific Name & Number \\
\hline Camomila & Chamomillarecutita (L.) Rauschert & 69 \\
Erva-doce & Foeniculumvulgare L. & 44 \\
CapimCidreira & Cymbopogoncitratus (DC.) Stapf & 18 \\
Boldo da Terra & Plectranthusbarbatus Andrews & 03 \\
Poejo & CunilafasciculataBenth. & 03 \\
Canela & Cinnamomumverum J. Presl & 02 \\
Alecrim & Rosmarinusofficinalis L. & 01 \\
Figatil & Vernoniacondensata Baker & 01 \\
Mastruz & Chenopodiumambrosioides L & 01 \\
\hline
\end{tabular}

Source: Elaborated by the author

With respect to medicinal plants, the botanical identification of species cited was not performed, and dome species used were acquired in vacant lots. Camomila, and Erva-doce were consumed more commonly in markets, Cinnamon was used as an emmenagogue and Mastruz was used to improve immunity. Canela caused backaches and cramps and Mastruz was continued even after interruption request by the health team. The influence of cultural factors could be observed since the user reported that she learnt the use of the medicinal plant from the motherandshe indicated that she did not to use gynecological or antibiotic ointments during pregnancy.

\section{DISCUSSION}

In this study, the average number of medicines consumed during pregnancy was 4.1 the same as that reported by Brum et al. (2011) and similar to the 4.6 and 4.2 reported by Araújo et al. (2013) and LunardiMaia et al. (2014), respectively. Costa et al. (2017) found that in the municipality of Santo Antônio de Jesus/BA which has a population and number of US similar to Umuarama/PR, among 924 pregnant women, the average number of medicines used was 2.41 , being 1.7 lower than our results. This suggests medicalization during the nine months of pregnancy is common as a woman may use vitamin supplements, analgesics, anti-emetic, anti-infectives and other medications as a result of signs and symptoms caused by hormonal changes, nutritional and/or pathological findings.

In this study, $13.8 \%$ of women had experienced abortion in previous pregnancies compared to $20.5 \%$ and $14.2 \%$ reported by Araújo et al. (2013) and Lunardi-Maia et al. (2014), respectively. Moreover, among the women in this study $26.2 \%$ of the interviewees were unaware of any risk due to medicinal products, which is higher than the $11.5 \%$ observed by Araújo et al. (2013). Thus, continuous health education is important to minimize unnecessary self-medication and ensure the safety of pregnant women.

The use of FDA category " $\mathrm{X}$ " medications was not observed in the studies by Araújo et al. (2013) and Guerra et al. (2008). However, in a study by Mengue et al. (2001), the prevalence of use of FDA category " $\mathrm{X}$ " medications were $0.6 \%$. Moreover, $9.3 \%, 0.3 \%$, and $3.0 \%$ of participants in the studies by Araújo et al. (2013), Guerra et al., (2008), and Mengue et al., (2001) were using FDA category "D" drugs, respectively. In this study, $12.2 \%$ and $2.4 \%$ of pregnant women were using FDA Category "D" and "X" drugs. When a drug is used during pregnancy, the benefits and risksto the mother and fetus should be assessed. The drug of choice should be the one that does not cause teratogenic effect or functional alteration (Brum et al., 2011). The category " $\mathrm{D}$ " medications include antiepileptics. The use of phenytoin, carbamazepine, valproate, lamotrigine, and phenobarbital has been associated with an increased risk for the development of major malformations or morphological abnormalities (Hirama et al., 2008). In the study by Guerra et al. (2008), of the four pregnant women who used medications included in risk category $\mathrm{D}$, two had been suffering from epilepsy, one was using phenobarbital alone, and the other, together with carbamazepine, both prescribed throughout the pregnancy period. Women with epilepsy of childbearing age should receive information before conception towards minimizing the risk of 
complications and maternal-fetal malformations (Hirama et al., 2008).

The majority of category " $\mathrm{X}$ " medicines in Umuarama/PR were sex hormones. A positive association was observed between the use of sexual hormones and congenital anomalies in a study by Pizzol et al. (2008). Moreover, most unplanned pregnancies are caused by failure of contraceptive method probably due to incorrect use of oral contraceptives (Lunardi-Maia et al., 2014). Thus, family planning is essential to avoid potential risks of an unplanned pregnancy, as well as ensuring the safety of the mother and the fetus. Regardless, this raises questions about the theme leads us to question the effectiveness of contraceptives, as well as the correct use of these drugs.

Regarding information for pregnant women, $19.5 \%$ of the interviewees by Melo et al. (2009) and $37.8 \%$ in Guerra et al. (2008) reported that they had not received guidance regarding the risks of certain medications during pregnancy. As indicated by Rodrigues et al. (2011), health professionals need to inform women about the risk of the use of medicinal plants and herbal medicines during pregnancy, and if the use of these are required, the duration of use should be the shortest possible time.

With respect to the use of alternative therapies, $31.0 \%$ of pregnant women in Brum et al. (2011) and 30.9\% in Araújo et al. (2016) reported the use of medicinal plants, whereas in our study this was $26.6 \%$ resulting in an average of 0.5 medicinal plants being used by the pregnant women. In a study by Mengue et al. (2001), phytotherapics were used in 55 cases $(0.6 \%)$, products composed of raw materials of vegetable origin associated with the substances isolated were used in 91 cases $(1.0 \%)$ and homemade teas were used in116 cases $(1.2 \%)$. The main guideline for pregnant women is not to use any medication, be it of plant origin or not without the prior knowledge of their doctor, because of the possible embryo toxic, abortive and teratogenic effects (Rodrigues et al., 2011).

In 2015, the municipality of Umuarama/PR received financial support from the Ministry of Health for inclusion of the project of phytotherapy in SUS according to a Decree no. 1.835 from November 13th 2015 (Diario Oficial, 2015), and in accordance with the national policy and program of medicinal and herbal medicines, expanding therapeutic options to users, ensuring access to medicinal plants, herbal medicines and services related to herbal medicine, with safety, efficacy and quality (Diario Oficial,
2006). The State of Rio de Janeiro also considers the role of phytotherapy within its health system and to better guide prescribers, it established the SES/RJ Resolution no. 1.757, dated from February 18th 2012 (Diario Oficial, 2012), which prohibits the use of medicinal plants reported to have abortive or emmenagogue effects in the scientific literature in the state of Rio de Janeiro.

Care protocols guarantee safety for both patients and health professionals, and it will be important for the municipality of Umuarama/PR to adopt such strategies as implemented in the state of Rio de Janeiro. According to Maeda \& Secoli (2008), protocols and guidelines regarding the use of drugs are not sufficient to ensure a risk-free practice, and that systematic actions of guidance and education in health, such as mandatory strategies are necessary in the promotion and prevention of diseases. The need for pharmacists in the primary health care units in order to ensure the rational use of medicines during pregnancy have been emphasized, with consequent decrease in problems due to inappropriate use of medicines (Araújo et al., 2013). In the municipality of Umuarama, the adequacy of local pharmaceutical assistance is necessary.

For the majority of medicinal plants, there are no data regarding the safety of their use during pregnancy or even if available, are usually scare and often contradictory (Rodrigues et al., 2011). Chamomile (Matricari arecutita L.) has pharmacological, anti-inflammatory, and antispasmodic activities and reports of allergic reactions to Chamomile are common (Rangel \& Bragança, 2009). The estrogenic activity of fennel (Foeniculum vulgare L.) has been proven by Malini et al. (1985) since the acetonic extract of the fruits caused an increase in the weight of the mammary glands and oviducts, endometrium, myometrium, cervix and vagina in rats. In this study, there was a medical request for interruption in the use of fennel tea following an increase in breast size after use of the product and this resolved after interruption in use. Moreover, there was report of allergy in the lower limb after use of chamomile tea with fennel. Medicinal plants contra-indicated in pregnancy and that are part of the project of insertion of phytotherapy in the municipality of Umuarama/PR include carqueja, mint, horsetail and chaguinha (Gorril et al., 2016).

\section{CONCLUSIONS}

This work reiterates the need to expand health 
promotion activities in basic units, implement protocols, technical guidelines as well as improve availability of pharmaceutical professionals to enhance education among the population. About 30\% of the pregnant women used medicinal plants during the gestational period with some contraindication and that, during antenatal consultations, no indication or information on the subject was obtained. Based on the information in this paper, we will undertake community projects, such as information leaflets and request the passage of municipal law, as done in the
State of Rio de Janeiro, to strengthen the incentive and safe use of medicinal and phytotherapeutic plants and to ensure compliance with the guidelines of the National Policy.

\section{ACKNOWLEDGMENTS}

We thank UNIPAR for the funding this research, and the Department of Health of the municipality of Umuarama/PR as well as the pregnant women for the constant collaboration.

\section{REFERENCES}

ANVISA [Agência Nacional de Vigilância Sanitária]. 2010. Resolução da Diretoria Colegiada - RDC Nº 60, de 17 de Dezembro de 2010. Estabelece frases de alerta para principios ativos e excipientes embulas e rotulagem de medicamentos. Publicado no D.O.U. Brasília, Brasil.

Araújo DD, Leal MM, Santos EJV, Leal LB. 2013. Consumption of medicines in high-risk pregnancy: evaluation of determinants related to the use of prescription drugs and self-medication. Braz J Pharmaceut Sci 49: 491 - 499. https://doi.org/10.1590/s1984-82502013000300010

Araújo CRF, Santiago FG, Peixoto MI, Oliveira JOD, Coutinho MS. 2016. Use of medicinal plants with teratogenic and abortive effects by pregnant women in a City in Northeastern Brazil. Rev Bras Ginecol Obstet 38: 127 - 131. https://doi.org/10.1055/s-0036-1580714

Brum LFS, Pereira P, Felicetti LL, Silveira RD. 2011. Utilização de medicamentos por gestantes usuárias do Sistema Único de Saúde no município de Santa Rosa (RS, Brasil). Ciência \& Saúde Coletiva 5: 2435 2442. https://doi.org/10.1590/s1413-81232011000500012

Costa DB, Coelho HLL, Santos DB. 2017. Utilização de medicamentos antes e durante a gestação: prevalência e fatores associados. Cad Saúde Pública 33: 126 - 215. https://doi.org/10.1590/0102-311x00126215

Diario Oficial. 2006. Decreto $\mathrm{N}^{\mathrm{o}}$ 5.813, de 22 de junho de 2006. Aprova a Política Nacional de Plantas Medicinais e Fitoterápicos e dá outras providências. Brasilia, Brasil.

Diario Oficial. 2012. Resolução SES/RJ N N $^{\circ}$.757, de 18 de Fevereiro de 2012. Contra indica o uso de plantas medicinais no âmbito do Estado do Rio de Janeiro e dá outras providências. Rio de Janeiro, Brasil.

Diario Oficial. 2015. Portaria $N^{\circ} 1.835$, de 13 de Novembro de 2015. Aprova o repasse dos recursos de investimento e custeio, em parcela única para os Municípios e Estados seleccionados pelo Edital SCTIE/MS No 2, de 24 de agosto de 2015. Brasilia, Brasil.

Gorril LE, Jacomassi E, Mella Junior SE, Dalsenter PR, Gasparotto Junior A, Lourenço ELB. 2016. Riscos das plantas medicinais na gestação: uma revisão dos dados de acesso libre em língua portuguesa. Arq Cienc Saúde UNIPAR 20: 67 - 72. https://doi.org/10.25110/arqsaude.v20i1.2016.5515

Guerra GCB, Silva AQB, França LB, Assunção PMC, Cabral RX, Ferreira AAA. 2008. Utilização de medicamentos durante a gravidez nacida de Natal, Rio Grande do Norte, Brasil. Rev Bras Ginecol Obstet 30: 12 - 18. https://doi.org/10.1590/s0100-72032008000100003

Hirama SC, Dias BCS, Matsudo ET, Gandolfo CG, Gandolfo CG, Ferreira BCG, Albuquerque M. 2008. Tratamento de gestantes com epilepsia: papel dos medicamentos antiepilépticos clássicos e novos. J Epilepsy Clin Neurophysiol 14: 184 - 192. https://doi.org/10.1590/s1676-26492008000400008

IBGE [Instituto Brasileiro de Geografia e Estatística]. 2020. População estimada. Disponível em https://cidades.ibge.gov.br/brasil/pr/umuarama/panorama

IPARDES [Instituto Paranaense de Desenvolvimento Econômico e Social]. 2017. Caderno estatístico Município de Umuarama, Paraná, Brasil.

Lacy CF, Armstrong LL, Goldman MP, Lance LL. 2009. Medicamentos Lexi-Comp Manole - uma fonte abrangente para médicos e profissionais da saúde. EditoraManole, Barueri, Brasil.

Lunardi-Maia T, Trevisol, FS, GalatoD. 2014. Uso de medicamentos no primeiro trimestre de gravidez: avaliação da segurança dos medicamentos e uso de ácidofólico e sulfato ferroso. Rev Bras Ginecol Obstet 36: 541 547. https://doi.org/10.1590/so100-720320140005051 
Kennedy DA, Lupattelli, A, Koren G, Nordeng H. 2016. Safety classification of herbal medicines used in pregnancy in a multinational study. BMC Complement Alt Med 16: 102. https://doi.org/10.1186/s12906-016-1079-z

Maeda ST, Secoli SR. 2008. Utilização e custo de medicamentos em gestantes de baixorisco. Rev Latinoam Enfermagem 16: 1 - 7.

Malini T, Vanithakumari G, Megala N, Anusya S, Devi K, Elango V. 1985. Effect of Foeniculum vulgare Mill. seed extract the genital organs of male and female rats. Ind J Physiol Pharmacol 29: 21 - 26.

Melo SCCS, Pelloso SM, Carvalho MDB, Oliveira NLB. 2009. Uso de medicamentos por gestantes usuárias do Sistema Único de Saúde. Acta Paul Enferm 22: 66 - 70.

https://doi.org/10.1590/s0103-21002009000100011

Mengue SS, Schenkel EP, Duncan BB, Schmidt MI. 2001. Uso de medicamentos por gestantes em seis ciudades brasileiras. Rev Saúde Pública 35: 415 - 420. https://doi.org/10.1590/s0034-89102001000500002

Monteiro SC, Brandelli CLC. 2017. Farmacobotânica - aspectosteóricos e aplicações. Artmed, Porto Alegre, Brasil.

Pizzol TSD, Sanseverino MTV, Mengue SS. 2008. Exposure to misoprostol and hormones during pregnancy and risk of congenital anomalies. Cad Saúde Pública 24: 1447 - 1453. https://doi.org/10.1590/s0102-311x2008000600025

Rangel M, Bragança FCR. 2009. Representações de gestantes sobre o uso de plantas medicinais. Rev Bras Plant Med 11: 100 - 109. https://doi.org/10.1590/s1516-05722009000100016

Rocha RS, Bezerra SC, Lima JWO, Costa FS. 2013. Consumo de medicamentos, álcool e fumo na gestação e avaliação dos riscos teratogênicos. Rev Gaúcha Enferm 34: 37 - 45. https://doi.org/10.1590/s1983-14472013000200005

Rodrigues HG, Meireles CG, Lima JTS, Toledo GP, Cardoso JL, Gomes SL. 2011. Efeito embriotóxico, teratogênico e abortivo de plantas medicinais. Rev Bras Plant Med 13: 359 - 366. https://doi.org/10.1590/s1516-05722011000300016

Silva MG, Gontijo EEL, Ferreira DS, Carvalho FS, Castro AM. 2015. O perfilepidemiológico de gestantes atendidas nas unidades básicas de saúde de Gurupi, Tocantins. Universitas: Ciências da Saúde. 13: 93 102. https://doi.org/10.5102/ucs.v13i2.3305

Smeriglio A, Tomaino A, TrombettaD. 2014. Herbal products in pregnancy: Experimental studies and clinical reports. Phytother Res 28: 1107 - 1116. https://doi.org/10.1002/ptr.5106

Yazbek PB, Tezoto J, Cassas F, Rodrigues E. 2016. Plants used during maternity, menstrual cycle and other women's health conditions among Brazilian cultures. J Ethnopharmacol 179: 310 - 331. https://doi.org/10.1016/j.jep.2015.12.054

Zomerdijk IM, Ruiter R, Houweling LMA, Herings RMC, Straus SMJM, Stricker BH. 2015. Dispensing of potentially teratogenic drugs before conception and during pregnancy: am population-based study. Int $\mathbf{J}$ Obstet Gynaecol 122: 1119 - 1129. https://doi.org/10.1111/1471-0528.13128 